Arq. Bras. Med. Vet. Zootec., v.64, n.4, p.1001-1008, 2012

\title{
Quail (Coturnixcoturnix japonica) welfare in two confinement systems
}

[Bem-estar de codornas (Coturnix coturnix japonica) em dois sistemas de confinamento]

\author{
W.M. Nordi, K.C.E. Yamashiro, M. Klank, R. Locatelli-Dittrich, R.N. Morais, \\ A.I. Reghelin ${ }^{3}$, C.F.M. Molento ${ }^{*}$
}

Universidade Federal do Paraná - UFPR - Curitiba, PA

\begin{abstract}
The intensification of animal production systems presents a potential impact on the welfare of animals. The objective of this work was to assess the welfare of quail Coturnixcoturnix japonicain two maintenance systems: battery cages (BC), and enriched aviary (EA),with saw-dust bedding, sand-bathing area and nests. The experiment procedure involved eight animals per holding area and four repetitions per treatment, an overall of 64 quails. Welfare was assessed through behavioral freedom, sanitary freedom (feather condition and injuries), blood analyses and glicocorticoid metabolites measurement in droppings. Results are presented in the BC order, followed by EA. Water drinking behavior and agonistic behavior were different between treatments $(\mathrm{P}<0.05)$. Feather condition was adequate in both treatments, except for the head in BC quails. Blood data were statistically different forred blood cells, hematocrit, hemoglobin, blood proteins, eosinophils, heterophils, lymphocytes and heterophil: lymphocyte ratio. Glicocorticoid metabolites levels were significantly different between maintenance systems. The behavioral and physiological welfare indicators showed higher welfare degree for quails in enriched aviary as compared to battery cages system.
\end{abstract}

Keywords: quail, behavioral freedom, corticosterone, hemogram, sanitary freedom

\section{RESUMO}

O objetivo deste trabalho foi avaliar o bem-estar de codornas (Coturnix coturnix japonica) em dois sistemas de manutenção: gaiolas industriais em baterias $(B C)$ e aviários enriquecidos (EA) com cama de serragem, caixa de areia e ninhos. $O$ procedimento experimental envolveu oito animais por área experimental equatrorepetiçõesportratamento, totalizando64codornas. $O$ bem-estar animal foi avaliado por meio da liberdade comportamental e da liberdade sanitária - condição das penas e ferimentos -, análises de sangue e mensuração de glicocorticoides nas fezes. Atividade de beber água e comportamento agonístico foram diferentes entre os tratamentos $(P<0,05)$. A condição das penas foi adequada em ambos os tratamentos, exceto para a condição das cabeças em codornas do tratamento BC. Os dados do sangue foram diferentes para eritrócitos, hematócrito, hemoglobina, proteínas sanguíneas, eosinófilos, heterófilos e linfócitos e para a relação heterófilo:linfócito. Os níveis de metabólitos glicocorticoides foram significativamente diferentes entre os sistemas de manutenção. Os indicadores comportamentais e fisiológicos de bem-estar mostraram alto grau de bem-estar para as codornas no EA em relação às no $B C$.

Palavras-chave:codorna,corticosterona, hemograma, liberdade comportamental, liberdade sanitária

\section{INTRODUCTION}

Quail farming foregg production in Brazil started in the beginning of the 70's. The importance of quail production as an alternative source of animal protein in Brazilian animal agriculture is increasing, reaching almost seven million animals in 2005 (Brasil, 2006). According to

Recebido em 25 de março de 2011

Aceito em 26 de março de 2012

*Autor para correspondência (corresponding author)

E-mail: carlamolento@yahoo.com available data (Brasil, 2006), the number of quails increased $9.5 \%$ in 2005 when compared to 2004, moving from 6,243,202 birds in 2004 to $6,837,767$ birds in 2005 . The main Brazilian states for quail production are São Paulo (36.8\%) and Espírito Santo (10.0\%). The states showing biggest recent increase in number of quails are Pernambuco (26.4\%) and Espírito Santo (15.8\%) (Brasil, 2006). 
Coupled with the increase in quail numbers, there was an increase in levels of production system intensification. Thus, quail egg production moved to industrial cage systems in crowded conditions, which brought restrictions to the natural behavior of the species, challenging the animals with the need for intense physiological and behavioral adaptations(Becker, 2002). Such caged systems are considered more economically efficient for the egg industry; however, there are negative effects on the welfare of laying birds (Onbaşilar and Aksoy, 2005). Therefore, there is an important animal life quality issue, especially when raising conditions are maintained throughoutthe major part of each animal's life. The provision of enriched environments, with nests, sand-bathing area and enough room for wing stretching and flipping might be a strategy to improve the welfare of egg-layers.
The five freedoms concept presents an option for on-farm animal welfare assessment, where an expanded interpretation might be employed (Molento, 2006), as well as immune system indicators (Gross and Siegel, 1993)and physiological parameters (Broom and Johnson, 1993). The objective of this work was to assess egg-laying quail welfare in two confinement systems,using behavioral and sanitary freedom, heterophil:lymphocyte ratio and glucocorticoid metabolites in droppingsas indicators.

\section{MATERIAL AND METHODS}

The experiment was conducted in the avian sector from March to August, 2006following the schedule showed in Figure 1. The different phases of on-field data collection were programmed to allow for efficient logistics, considering adequate time availability for each task.

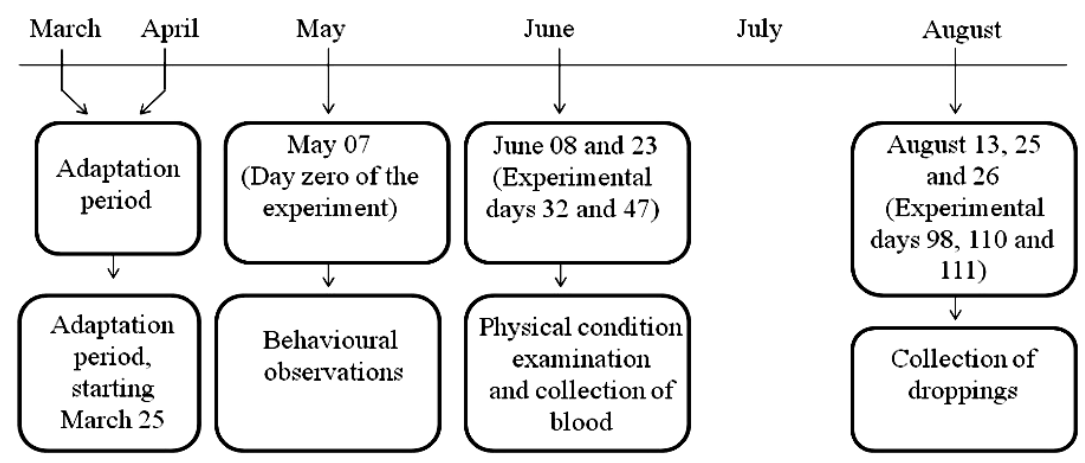

Figure 1. Experimental schedule, Centro de Estações Experimentais do Canguiri, Universidade Federal do Paraná, South of Brazil, 2006.

The experimental use of the animals was approved by the Animal Use Ethics Committee of the Agrarian Sector of the Universidade Federal do Paraná. The design involved 64 egglaying quails (Coturnixcoturnix japonica),65day-old, from a commercial seller. The birds were maintained in two different confinement systems: battery cages (BC) measuring $45 \times 60 \times 26.5 \mathrm{~cm}$, and enriched aviaries (EA) measuring $108 \times 144 \times 162 \mathrm{~cm}$, with four repetitions per treatment. In each system, there were eight animals per cage or aviary, characterizing an animal density of 29.6 and 5.2 quails $/ \mathrm{m}^{2}$, respectively. The cages were arranged in the battery with two rows and two cages per row. The aviaries were enriched with $2.5 \mathrm{~cm}$ saw-dust bedding, sand-bathing area of $0.30 \times 1.10 \mathrm{~cm}$, three perches and two wood nests measuring $0.25 \times 0.11 \times 0.10 \mathrm{~cm}$. Cages and aviaries werekept at the same facility, with similar environmental factors such as water availability, ad libitum feeding, natural lighting and ventilation. Quail welfare was assessed through the study of behavioral and sanitary freedom, hemogram and glucocorticoid metabolites measurement in droppings.

The first day of behavioral freedom observations, after the $43 \mathrm{~d}$ adaptation period, was considered day zero in the experiment (Figure 1). Starting two days before the beginning of behavioral observations, three birds per cage or aviary were individually marked with non-toxic multicolored paint on their backs to allow for individual bird 
recognition. Thus, behavioral occurrences of 12 birds per treatment were registered, in two different days, during eleven consecutive hours, from dawn (7:00h AM) until sunset (6:00h PM). Behavior was registered through focal instantaneous sampling, each five minutes (Martin and Bateson, 1993). Behavior was registered using two different checklists, each one specific for each treatment. Data collection was conducted by the Laboratório de Bem-estar Animal (LABEA, UFPR) team, each observer at one meter distance from the cage or aviary door. Behavioral activities were analyzed statistically through descriptive statistics and for behavioral data on total number of observations of each activity per day, treatments were compared through the Mann Whitney test.

Sanitary freedom was evaluated through feather condition and incidence of injury. For physical examination each bird was manually restricted and examined by the same person to assess feather condition and incidence of injuries. Feather condition was categorized in one of the following classes: one - perfect feather condition or slight feather damage; two feathers missing in the region of head, back or chest; and three - feathers totally damaged or absent from most of the body surface. Feather condition and injury data were analyzed statistically through descriptive statistics.

For blood analyses, samples ofblood (1\% body weight) from 56 birds were collected from the brachial vein. Blood samples were transferred to a tube containing ethylenediaminetetraacetic acid (EDTA). Thin smears were made immediately after blood collection. Hematological analyses were conducted according to Jain (1986). Total red blood cell (RBC) and total white blood cell (WBC) counts were performed through a manual method using hemocytometer, with $0.01 \%$ toluidine blue stain diluted in the blood. The hemoglobin concentration was measured through the cyanmethemoglobin method. The packed cell volume (PCV)was measured in microhematocrit capillary tubes and centrifuged at $2500 \mathrm{rpm}$ for 5 min. Mean corpuscular volume (MCV) and mean corpuscular hemoglobin concentration (MCHC) were calculated employing the same formulas used for mammals (Jain, 1986; Thrall, 2007). Leukocyte differential counts were made on blood films stained with Wright's stain, using an average of 200 leukocytes. The heterophil:lymphocyte ratio was calculated dividing heterophil by lymphocyte percentages. Blood data were compared between treatments with the SAS Mixed Procedure, with animals as repeated measures.

For measurement of glucocorticoid metabolites in droppings, 24 droppings samples from each treatment were collected in three different daysin August, in a total of 48 samples. The saw-dust bedding in aviaries and the floor surface of the cages were covered with a plastic sheet, and droppings were collected immediately after eliminatory behavior. Sample collection in EA involved entering the birds' space, a greater stressor than the plastic sheet covering of cage floors. All samples were stored in plastic bags, and frozen $\left(-20^{\circ} \mathrm{C}\right)$ until further processing. After liofilization, each sample was weighed and steroids were extracted, as previously described(Popp et al., 2008), with modifications. Briefly, aliquots of $0.4 \mathrm{~g}$ of dry homogenized dropping samples were then transferred to a $2.5 \mathrm{~mL}$ tube containing $90 \%$ ethanol in phosphate-buffered saline (PBS). After 30minof vortex agitation, tubes were centrifuged $(1,500 \mathrm{X}$ $\mathrm{g} / 15 \mathrm{~min})$, extract was diluted in PBS $(1: 1)$ and frozen $\left(-20^{\circ} \mathrm{C}\right)$ until further processing. Glucocorticoid metabolite concentrations were measured in duplicates, with $100 \mu \mathrm{L}$ aliquots of steroid extract, employing radioimmuneassay with ${ }^{125}$ I-corticosterone double commercial antibody (Corticosterone ICN Biomedicals, USA). The antiserum description was characterized by the cross-reaction of $100 \%$ corticosterone, $\quad 0.34 \%$ desoxicorticosterone, $0.10 \%$ testosterone, $0.05 \%$ cortisol, $0.03 \%$ aldosterone, $0.02 \%$ progesterone and $0.01 \%$ and rostenedione. These were validated for other bird species (Wasseret al., 1997) and for quails, by the parallelism between dilutions $(1: 2 ; 1: 4 ; 1: 10$; $1: 20 ; 1: 40 ; 1: 80)$ of a pooled sample and the standard curve.

The efficiency of the dropping extraction process was monitored by the addition of ${ }^{3} \mathrm{H}$-cortisol to each tube at the beginning of the extraction, and the average recovery was $89 \%$. The results for dropping corticosteroids were corrected by the average recovery and are shown as ng/g of dry droppings. Glucocorticoid metabolites were statistically analyzed with the SAS,GLM Procedure. 


\section{RESULTS}

All results are shown in the order of BC treatment followed by EA treatment. EA quails showed the saw-dust bedded floor (1516 observations) and the sand-bathing area (1366 observations) as preferential sites; they were also seen in the nest (226 observations) and on top of the nest (26 observations). On $56 \%$ and $46 \%$ of the observations birds were seen standing, $29 \%$ and $40 \%$ sitting, and $15 \%$ and $13 \%$ walking $(\mathrm{P}>0.05)$. The medians of each behavioral activity per animal per day were compared between treatments (Table 1). There was a significant difference $(\mathrm{P}<0.05)$ between treatments for water drinking and agonistic behavior.

Feather condition class one was observed for both treatments, except for the head of quails in $\mathrm{BC}$, in which $15.6 \%$ showed missing feathers, categorized then as class two. In relation to injuries, from 32 quails in $\mathrm{BC}$, five birds (15.6\%) showed skin injuries on the head and back. For EA, 32 birds were in good feather condition and no injuries were observed.

Table 1. Ethogram of 12 quails per treatment, in battery cages (BC) or enriched aviaries (EA), two days of observation, 11 consecutive hours during the light period

\begin{tabular}{|c|c|c|}
\hline \multirow[t]{2}{*}{ Behavioral activity } & \multicolumn{2}{|c|}{$\begin{array}{l}\text { Number of observations, instantaneous sampling } \\
\text { (Ethogram, \%) }\end{array}$} \\
\hline & $\mathrm{BC}$ & EA \\
\hline Eating & $560(13,32) a$ & $375(8,41) \mathrm{a}$ \\
\hline Drinking & $112(2,66) \mathrm{a}$ & $55(1,23) \mathrm{b}$ \\
\hline Agonistic behavior & $94(2,24) \mathrm{a}$ & $24(0,54) b$ \\
\hline Wing flapping & $5(0,12) \mathrm{a}$ & $1(0,02) a$ \\
\hline Open beak & $4(0,10)$ & $0(0,00)$ \\
\hline Vocalization & $15(0,36) \mathrm{a}$ & $3(0,07) a$ \\
\hline Sand bathing & - & $126(2,38)$ \\
\hline Walking & $460(10,94) a$ & $418(9,37) \mathrm{a}$ \\
\hline Self-grooming & $285(6,78) a$ & $330(7,40) \mathrm{a}$ \\
\hline Floor pecking & $7(2,28) \mathrm{a}$ & $34(5,63) \mathrm{a}$ \\
\hline Flying & - & $18(0,40)$ \\
\hline
\end{tabular}

Different letters on the same row indicate significant differences $(\mathrm{P}<0.05)$ between treatments by Mann-Whitney test. Statistical analysis was not performed when the number of observations for one of the treatments was zero.

Blood results (Table 2) refer to the analyses of 55 blood samples, due to cell degeneration in one blood sample. There were significant differences between treatments forerythrocytes, hematocrit, plasma proteins, hemoglobin, and eosinophils. The detailed information on the significant difference between treatments regarding heterophils, lymphocytes and heterophils: lymphocyte ratiosis shown in Figure 2. Glucocorticoid metabolite concentrations were $32.1 \pm 3.2$ and $41.5 \pm 3.2 \mathrm{ng} / \mathrm{g}$ of droppings $(\mathrm{P}<0.05)$ for $\mathrm{BC}$ and $\mathrm{EA}$, respectively.

Table 2. Hematological values (mean \pm standard error) from 55 quails in either battery cages or enriched aviaries

\begin{tabular}{lcc}
\hline Parameter & Battery Cages & Enriched Aviaries \\
\hline WBC $(/ \mu \mathrm{L})$ & $24,267.0 \pm 2,010.8 \mathrm{a}$ & $25,680.0 \pm 2,202.8 \mathrm{a}$ \\
Eosinophils $(\%)$ & $6.27 \pm 0.52 \mathrm{a}$ & $4.48 \pm 0.57 \mathrm{~b}$ \\
Monocytes $(\%)$ & $1.96 \pm 0.49 \mathrm{a}$ & $2.80 \pm 0.54 \mathrm{a}$ \\
Basophils $(\%)$ & $1.57 \pm 0.23 \mathrm{a}$ & $1.40 \pm 0.21 \mathrm{a}$ \\
Band heterophils $(\%)$ & $0.53 \pm 0.18 \mathrm{a}$ & $0.040 \pm 0.20 \mathrm{a}$ \\
RBC $\left(x ~ 10^{6} / \mu \mathrm{L}\right)$ & $2.76 \pm 0.12 \mathrm{a}$ & $3.80 \pm 0.13 \mathrm{~b}$ \\
PCV $(\%)$ & $42.2 \pm 0.7 \mathrm{a}$ & $48.7 \pm 0.8 \mathrm{~b}$ \\
Plasma total protein $(\mathrm{g} / \mathrm{dL})$ & $5.45 \pm 0.27 \mathrm{a}$ & $4.52 \pm 0.29 \mathrm{~b}$ \\
Hemoglobin $(\mathrm{g} / \mathrm{dL})$ & $16.43 \pm 0.27 \mathrm{a}$ & $18.48 \pm 0.30 \mathrm{~b}$ \\
Heterophils $\%)$ & $29.88 \pm 1.91 \mathrm{a}$ & $20.85 \pm 2.05 \mathrm{~b}$ \\
Lymphocytes $(\%)$ & $59.43 \pm 2.13 \mathrm{a}$ & $70.76 \pm 2.32 \mathrm{~b}$ \\
\hline
\end{tabular}

Means followed by different letters on the same row indicate significant differences $(\mathrm{P}<0.05)$; Proc Mixed, SAS. 


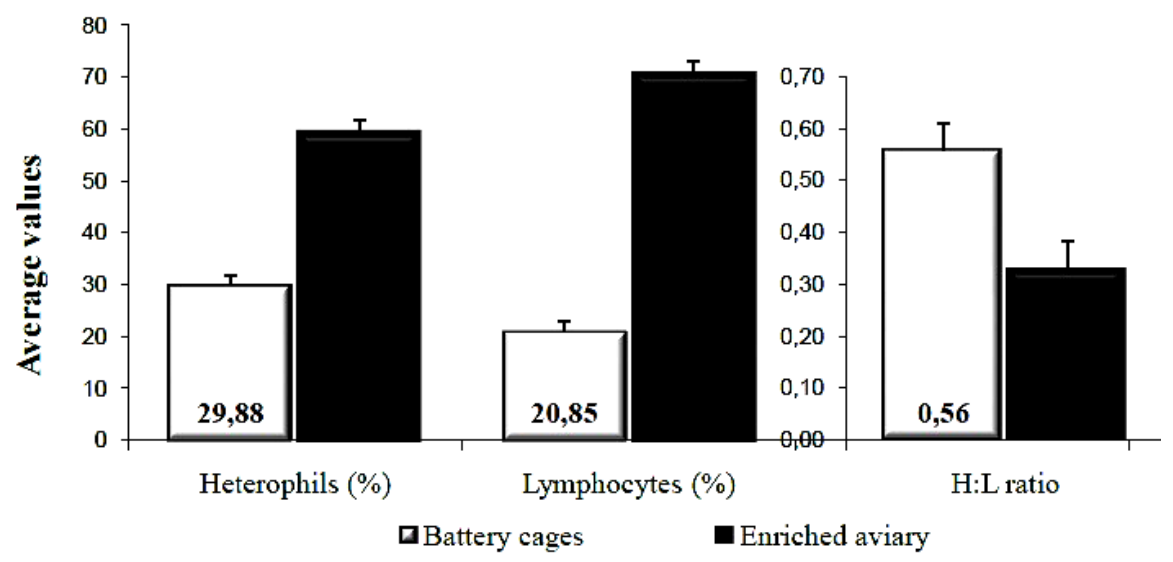

Figure 2. Average values for heterophils $(\mathrm{H})$, lymphocytes $(\mathrm{L})$ and heterophil/lymphocyte ratio $(\mathrm{H}: \mathrm{L})$ from 64 quails confined in battery cages or enriched aviaries; all differences were statistically significant $(\mathrm{P}<0.05)$.

\section{DISCUSSION}

The confinement systems studied showed that $\mathrm{BC}$ gave no opportunities for the natural quail behavioral repertoire to be expressed, due to environmental restrictions. In their natural habitat, quails use varied food resources, such as forage, fruits, grains, leaves, insects and larvae (Schmid and Wechsler, 1997). According to the same authors, food search and consumption activities fill great part of quail daylight time. In our experimental conditions, quails spent $18.2 \%$ and $15.2 \%$ of daylight time expressing food ingestive behavior. Additionally, Schmid and Wechsler (1997)observed quails moving, walking and running $24 \%$ of the time, and pecking, scratching and stretching $8 \%$ of the time. These percentages are higher than those found in our study, where quails spent $10.9 \%$ and $9.8 \%$ of the time moving, walking and running and $2.3 \%$ and $5.6 \%$ pecking. Flying percentage was $0.4 \%$, apparently higher than that observed by Schmid and Wechsler (1997), of 0.01\%. Sand bathing and self-grooming percentages expressed by our animals were in accordance with values found by Schmid and Wechsler (1997), 2.2\% and $11.6 \%$, respectively.

Floor characteristics affect leg problems in laying hens, better floors offer more comfort and higher welfare to the birds, according to the Directive 1999/74/EC (European..., 1999). Although leg problems are not reported for laying quails, our results showed that quails on the more comfortable EA floor spent a significantly higher proportion of time sitting when compared to $\mathrm{BC}$ quails, which in turn spent longer periods standing.

The higher frequency of agonistic interactionin BC confirms the hypothesis that systems providing severely restricted space per bird are not satisfactory in terms of animal welfare (Weeks and Nicol, 2006). Onbaşilar and Aksoy (2005) also reported higher excitation and increased events of aggressive behavior in laying hens kept in high stocking densities (1968, 656 and $393.8 \mathrm{~cm}^{2} / \mathrm{hen}$ ). Increased agonistic behavior can be interpreted as lower welfare (Broom and Johnson, 1993); considering this indicator, EA was related to higher quail welfare. Some behavioral activities were not observed during this experiment, such as laying, brooding and perching.

There were different behavioral patterns for quails in each treatment, suggesting higher behavioral freedom in EA. This is shown by the fact that EA made it possible for the animals to exhibit a richer behavioral repertoire, including an increase in highly motivated activities such as pecking, sand bathing and sitting during resting periods, and a decrease in agonistic interaction. Thus, according to behavioral indicators, quail welfare was higher in EA if compared to BC.

According to Fraser and Broom (1990), aggressive feather pecking between different 
individuals is a type of abnormal behavior resulting from the frustration of exploratory behavior in a sterile environment, where the feathers from other birds are interpreted as substitutes for high motivation activities such as floor pecking and scratching. Additionally, crowding conditions seem related to feather conditions (Onbaşilar and Aksoy, 2005). The same authors, working with laying hens in three different densities, observed that as animal density increased, feather condition decreased. Leandro et al., (2005) working with quails subjected to different debeaking, reported that debeaked birds showed better feather conditions than non-debeaked groups. However, debeaking is in itself a factor that acutely decreases welfare, with evidence of an additional chronic impact due to the formation of neuromas (Breward and Gentle, 1985). When quails were exposed to more space and richer environments, there were no feather or skin problems in non-mutilated birds. In addition to feather condition, there was one event of cloacalprolapse in one quail in BC treatment during venipuncture for blood sample collection. Results suggest higher welfare in EA, as evidenced by the absence of feather problems and injuries in this treatment.

Values reported by Aengwanich and Chinrasri (2003) for eosinophils $(2.4 \%)$ and lymphocytes $(50.9 \%)$ were lower than the ones found in the present study; for monocytes $(3.5 \%)$, basophils (1.9\%), heterophils (41.2\%), and H:Lratio (0.80), values reported were higher. Locatelli-Dittrich et al. (1999), studying hematological parameters for adult meat quails in an industrial system, found $39.6 \pm 4.3 \%$ hematocrit, $3.83 \pm 1.06 \mathrm{~g} / \mathrm{dL}$ plasma proteins, and $11.68 \pm 1.68 \mathrm{mg}$ hemoglobin/dL, relatively lower values when compared to both treatments of the present work. Many factors might be related to these differences, for instance, the age of the birds, diet, sex and environmental factors, and stress (Herbert et al., 1989; Thrall, 2004; Schmidt et al., 2007). The differences between treatments in $\mathrm{RBC}, \mathrm{PCV}$ and hemoglobin were not part of the working hypotheses and warrant further investigation. The $\mathrm{H}: \mathrm{L}$ ratio increases as stress increases and life quality decreases, indicating decreasing welfare status (Gross and Siegel, 1983; McFarlane and Curtis, 1989; Cravener et al., 1992). H:L ratio results showed that quails kept in BC experimented a lower welfare degree when compared to EA.
Gross and Siegel (1993) propose three categories of stress in hens, based on H:L ratio: 0.2 low stress, 0.5 intermediate stress, and 0.8 high stress. Being indicators of chronic stress, these levels may be employed in terms of hen welfare, the lowest level of stress corresponding to the highest level of welfare. $\mathrm{H}: \mathrm{L}$ ratio values for quails in BC and EA seem coherent with the categories proposed by Gross and Siegel (1993) for hens. Employing these categories, quails in BC fall in the category of intermediate stress, and quails in EA are between the categories of intermediate and low stress. This classification suggests that the welfare of quails in EA is higher than the welfare in BC. Additionally, the $\mathrm{H}: \mathrm{L}$ ratio observed by our group in typical industrial battery cages at the UFPR quail production unit, which employ higher densities (42.8 quails $/ \mathrm{m}^{2}$ ) than our BC treatment, was1.6 \pm 0.6 , above the high stress category, and very low welfare degree. The range of $\mathrm{H}: \mathrm{L}$ values observed in our work supports the hypothesis that the same categories created for hens is useful for quail stress and welfare diagnosis. The results confirm the proposal that $\mathrm{H}: \mathrm{L}$ ratio is an appropriate index to evaluate chronic stressin intensive production systems (McFarlane and Curtis,1989), and an appropriate additional welfare indicator. Quail hematological values reported here aid the construction of reference values for this species.

Onbaşilar and Aksoy (2005) observed high plasma glucocorticoid levels in hens kept in high densities, and concluded that laying hens were coping under stressful conditions. Following the same trend, glucocorticoid metabolite levels in droppings observed in our laboratory for quails in a typical intensive battery cage system was $74.6 \pm 31.1 \mathrm{ng} / \mathrm{g}$ of droppings, presenting much higher average as well as greater variance as compared to values presented here. Levels of glucocorticoid metabolites observed in the present study were higher for quails in EA compared to BC. Factors which might have contributed to higherglucocorticoid levels in EA are the greater possibility of physical activity for quails in this treatment and the potentially higher impact of the droppings collection procedure, due to more pronounced alteration of contact surface (bedding to plastic and wire to plastic in $\mathrm{EA}$ and $\mathrm{BC}$, respectively) and the entry of a person within the EA environment to install the plastic cover, which is likely to cause greater 
general bird activity, that in turn might have caused increased glucocorticoid secretion and excretion to droppings, since there was a time interval from $30 \mathrm{~min}$ to a couple of hours from plastic installation to first defecation. Regarding the relationship between physical activity and corticoid levels, it is known that voluntary exercise increases corticoid secretion (Squires, 2003). Quails in EA performed behavioral activities of high muscle activity demand, such as sand-bathing, which were not possible for quails in $\mathrm{BC}$, and it is likely that behavioral repertoire in both treatments influenced glucocorticoid levels. Craig and Craig (1985) did not find significant differences in glucocorticoids when comparing confinement systems. Mcfarlane and Curtis (1989) considered leucocyte responses to stressful conditions as less variable than glucocorticoid responses. Additionally, Cunningham et al. (1988) and Craig and Craig (1985) reported that glucocorticoid levels might not be useful for chronic stress measurement. Our results corroborate the idea that $\mathrm{H}: \mathrm{L}$ ratio as a more reliable markerof chronic welfare status than steroids, as in Maxwell (1993) and Shini (2003).

\section{CONCLUSIONS}

The differences observed between the maintenance systems support the idea that there are improvements in behavioral freedom, sanitary freedom and blood parameters in quails maintained in enriched aviaries. Although levels of glucocorticoid metabolites in droppings seem to be good welfare indicators in extreme situations, its power in terms of animal welfare assessment when differences are less intense and more chronic seems reduced. The agreement amongst all other indicators employed suggests higher laying quail welfare in enriched aviaries when compared to battery cages.

\section{AKNOWLEDGEMENTS}

We are thankful for the collaboration of people without whom this work would not have been possible: professor Edson G. de Oliveira, for the support of the UFPR Poultry Sector, students Edson Faria, Auana Olsen, Dayana Swaroski, Gilmara Mansani, Gabriella de O. Martha, Francisco Rosa, Suzana Gilaverte, for helping during behavioral observations, blood sampling and facility preparation and maintenance; students Lia Fordiani Lenati, Paula Linder, Nicole Plugge, Nina Cunha Medeiros and Ítalo Ruiz, from Laboratory of Veterinary Clinical Pathology, UFPR, for help with blood analyses.

\section{REFERENCES}

AENGWANICH, W.; CHINRASRI, O. Effect of dexamethasone on differential white blood cell counts and heterophil/lymphocyte ratio in Japanese quails (Coturnixcoturnixjaponica). J. Sci. Technol., v.25, p.183-189, 2003.

BECKER, B.G. Comportamento das aves e sua aplicação prática. In: Conferência apinco de ciência e tecnologia avícolas. Fundação APINCO de Tecnologia e Ciência Avícolas. p.81-90, 2002.

BRASIL. IBGE - Instituto Brasileiro de geografia e estatística, 2006. Produção da Pecuária Municipal 2005, Comunicação Social,11 de dezembro de 2006. Acessado em: 20/abr/2008. Available on: http://www.ibge.gov.br/home/presidencia/noticia s/noticia_impressao.php?id_noticia=759> access on May 2008.

BREWARD, J.; GENTLE, M.J. Neuroma formation and abnormal efferent nerve dischanges after partial beak amputation (beak trimming) in poultry. Experientia, v.41, p.11321134, 1985.

BROOM, D.M.; JOHNSON, K.G. Stress and animal welfare. The Netherlands: Kluwer Academic Publishers, 1993. p.211.

CRAIG, J.V.; CRAIG, J.A. Corticosterone levels in white leghorn hens as affected by handlying, laying-house environment, and genetic stock. Poult. Sci., v.64, p.809-816, 1985.

CRAVENER, T.L.; ROUSH, W.B.; MASHALY, M.M. Broiler production under varying population densities. Poult. Sci. v.71, p.427-433, 1992.

CUNNINGHAM, D.L.; VAN TIENHOVEN, A.; GVARYAHU, G. Population size, cage area, and dominance rank effects on productivity and wellbeing of laying hens. Poult. Sci., v.67, p.399406, 1988. 
EUROPEAN union, 1999. Council Directive 1999/74/EC of 19 July 1999 laying down minimum standards for the protection of laying hens.Off. J. Eur. Communities, L 203, 03/08/1999, p.53-57.

FRASER, A.F.; BROOM, D.M. Farm animal behaviour and welfare. London: Baillière Tindall, 1990. p.437.

GROSS, W.B.; SIEGEL, H.S. Evaluation of the heterophil/lymphocite ratio as a measure of stress in chickens. Avian Dis., v.27, p.972-979, 1983.

GROSS, W.B.; SIEGEL, H.S. General principles of stress and welfare. In: TEMPLE, G. Livestock handling and transport. Wallingford, UK.: CAB International, 1993. p.21-34.

HERBERT, R.; NANNEY, J.S.; SPANO, W.M. et al. Erythrocyte distribution in ducks. Am. J. Vet. Res., v.50, p.958-960. 1989.

JAIN, N.C. Schalm's Veterinary Hematology. Philadelphia: Lea and Febiger. 1986. 1221 p.

LEANDRO, N.S.M.; VIEIRA, N.S.; MATOS, M.S. et al.Desempenho produtivo de codornas japonesas (Coturnix coturnix japonica) submetidas à diferentes densidades e tipos de debicagem. Acta Scientiarum, v.27, p.129-135, 2005.

LOCATELLI-DITTRICH， R.; PERAZZOLI, G.P.; SCHMIDT, E.M.S. et al. Determinação de parâmetros hematológicos em codornas (Coturnix coturnix) de criação industrial. Arch. Vet. Sci., v.4,. 1999. Available on: http://ojs.c3sl.ufpr.br/ojs2/index.php/veterinary/a rticle/view/3806/3046. Acessado em: 21 jun.2012.

MARTIN, P.; BATESON, P. Measuring behaviour: an introductory quide. 2.ed. Cambridge: Cambridge University Press, 1993. p. 222.

MAXWELL, M.H. Avian blood leucocyte responses to stress. Br. Poult. Sci., v.49, p.34-43, 1993.

McFARLANE, J.M.; CURTIS, S.E. Multiple concurrent stressors in chicks. 3. Effects on plasma corticosterone and the Heterophil: Lymphocyte ratio. Poult. Sci., v.68, 522-527, 1989.
MOLENTO, C.F.M. Rethinking the five freedoms. In: I Congresso Internacional de conceitos em Bem-estar Animal - Teoria, Docência, Aplicação, 1., 2006, Rio de Janeiro. Annals..., Rio de Janeiro: WSPA. 2006. Available on: http://www.labea.ufpr.br/ resumos.html. Acessado em: 21 jun. 2012.

ONBAŞILAR, E.E.; AKSOY, F.T. Stress parameters and immune response of layers under different cage floor and density conditions. Livest. Prod. Sci., v.95, p.255-263, 2005.

POPP, L.G.; SERAFINI, P.P.; REGHELIN, A.L. et al. Annual pattern of fecal corticoid excretion in captive Red-tailed parrots (Amazona brasiliensis). J. Comp. Physiol. [B], v.178, p.487-493, 2008.

SCHMID, I.; WECHSLER, B. Behaviour of Japanese quail (Coturnix japonica) kept in seminatural aviaries. Appl. Anim. Behav. Sci., v.55, p.103-112, 1997.

SCHMIDT, E.M.S.; PAULILLO, A.C.; LOCATELLI-DITTRICH, R.et al. The effect of age on hematological and serum biochemical values on juvenile ring-necked pheasants (Phasianus colchicus). Int. J. Poult. Sci., v.6, p.459-461, 2007.

SHINI, S. Physiological responses of laying hens to the Alternative Housing Systems. J. Poult. Sci., v.2, p.357-360, 2003.

SQUIRES, E.J. Applied Animal Endocrinology. Oxon: CAB International, 2003. 233p.

THRALL, M.A.; BAKER, D.C.; CAMPBELL, T.W. Hematologia e Bioquímica Clínica Veterinária. São Paulo: Editora Roca, 2007. $592 \mathrm{p}$.

WASSER, S.K.; BEVIS, K.; KING, G.et al.Noninvasive physiological measures of disturbance in the Northern Spotted Owel. Conservation Biology, v.11, p.1019-1022, 1997.

WEEKS, C.A.; NICOL, C.J. Behavioural needs, priorities and preferences of laying hens. World's Poult. Sci. J., v.62, p.296-307, 2006. 